\title{
Children and the wave of destruction
}

\author{
Pushpa M G Punchihewa \\ Sri Lanka Journal of Child Health, 2007; 36: 84-95
}

(Key words: tsunami, 26 December 2004, Sri Lanka, Galle district, children)

The tsunami in the morning, on the 26th of December 2004, triggered by an undersea earthquake $30 \mathrm{~km}$ below sea floor in the Indian Ocean off Indonesia, at $06.58 \mathrm{hrs}$ local time, resulted in a natural disaster of apocalyptic proportions $^{1}$. The energy released by the earthquake is approximately 23,000 Hiroshima sized atomic bombs ${ }^{1}$. The giant killer waves that travelled hundreds of kilometres up to $800 \mathrm{~km}$ per hour across the Indian Ocean, devastated cities, and seaside communities displacing hundreds of thousands and took over 200,000 lives in a dozen countries ${ }^{1}$.

Sri Lanka, largely regarded to be free from natural disasters, was one of the worst hit countries, causing destruction to more than two thirds of its coastal belt, the worst devastation being in Ampara, Galle and Mullaitivu. First wave hit Galle at 09.00 hours and the second wave hit Galle at 09.36 hours local time. No one thought that an ordinary Sunday at the very end of the year could turn into a nightmare for thousands of people across the country.

Tsunami disaster statistics from the National Disaster Management Centre as at 27.01.2005 are shown in Tables 1, 2 and 3.

\section{Table 1}

\begin{tabular}{|l|c|}
\hline Sri Lanka & Number \\
\hline Number of deaths & 30,959 \\
\hline Number of missing persons & 5,644 \\
\hline Number of displaced persons & 500,668 \\
\hline
\end{tabular}

Table 2

\begin{tabular}{|l|c|}
\hline Southern Province & Number \\
\hline Number of deaths & 10,060 \\
\hline Number of missing persons & 2,130 \\
\hline Number of displaced persons & 157,694 \\
\hline
\end{tabular}

${ }^{1}$ Consultant Paediatrician, Teaching Hospital, Karapitiya.
Table 3

\begin{tabular}{|l|c|}
\hline Galle district & Number \\
\hline Number of deaths & 4,218 \\
\hline Number of missing persons & 554 \\
\hline Number of displaced persons & 127,754 \\
\hline
\end{tabular}

The objective of my presentation is to illustrate the impact of tsunami on children and their families in Galle district. This is presented in 4 stages.

- Stagel Immediate physical and psychological impact.

- Stage2 Problems of immediate post disaster phase.

- $\quad$ Stage3 Traumatic stress reactions following tsunami.

- Stage4 Impact and challenges of temporary shelters.

\section{Why were children particularly at risk?}

UNICEF reported that children accounted for a large proportion of casualties. They represent $39 \%$ of the overall population in the 8 hardest hit countries $^{2}$. Though the children can run, they were least able to withstand the floods and weren't strong enough to hold on to fixtures. Many were swept away to their deaths, while a considerably larger number were separated from their parents and family members. Others lost all their belongings. Some others were left with physical and psychological disability. It is unfortunate that the poor children of the fishing communities who are already deprived physically and socially were affected most in many different ways. 
Injuries, drowning and near drowning accounted for the vast majority of mortality and morbidity experienced after tsunami.

\section{Definition of Drowning and near drowning}

After submersion in a liquid medium, suffocation and asphyxia may occur with or without pulmonary aspiration. Irreversible multi systemic injury occurs very rapidly, often leading to death ${ }^{3}$. Death within 24 hours of submersion is termed drowning, which may be immediate or may follow resuscitation ${ }^{3}$. Survival for more than 24 hours is termed near drowning, regardless of whether the victim later dies or recovers ${ }^{3}$.

\section{Pathophysiology of drowning and near drowning}

The principal physiological consequences of immersion injury are prolonged hypoxaemia and acidosis ${ }^{3}$. It affects all organs and tissues and the severity of injury depends on the duration of immersion. After initial gasping and possible aspiration, there is hyperventilation, followed by voluntary apnoea and a variable degree and duration of laryngospasm. This leads to hypoxaemia. Depending upon the degree of hypoxaemia and resultant acidosis, the person may develop cardiac arrest and tissue ischaemia ${ }^{3}$. Asphyxia leads to relaxation of the airway, which permits the lungs to take in water in many individuals ("wet drowning"), although most patients aspirate less than $4 \mathrm{ml} / \mathrm{kg}$ of fluid. If there is associated pulmonary aspiration, hypoxaemia and respiratory failure are exacerbated ${ }^{3}$. On the other hand approximately $10-20 \%$ of individuals maintain tight laryngospasm until cardiac arrest occurs and inspiratory efforts cease. These victims do not aspirate any appreciable fluid ("dry drowning") $)^{3}$.

\section{Central Nervous System (CNS) injury}

All organs can be damaged from hypoxaemia, but the brain is highly sensitive. CNS injury is now the most frequent cause of mortality and long-term morbidity ${ }^{3}$. Although the duration of hypoxaemia needed for irreversible CNS damage is uncertain, it is probably of the order of 3-5 minutes. Generalised neuronal death as a result of ischaemia, leads to cytotoxic cerebral oedema and increased intracranial pressure causing further CNS injury \& seizures ${ }^{3}$. Hyperglycaemia as a result of triggered pathogenic cascades has also been implicated in exacerbating CNS injury $^{3}$. After near drowning, children with initial blood glucose of over $300 \mathrm{mg} / \mathrm{dl}$ are more likely to die or survive in a persistent vegetative state compared with normoglycaemic victims ${ }^{3}$.

\section{Pulmonary aspiration}

Pulmonary aspiration occurs in $85-90 \%$ of nearly drowned victims ${ }^{3}$. However, in the great majority of cases the amount of fluid aspirated is small. A few children may have massive aspiration, causing severe pulmonary dysfunction, fluid shifts, or electrolyte abnormalities $^{3}$. The composition of the aspirated material too, affects the patient's clinical condition. Grossly contaminated water creates a risk of severe pulmonary infections. The gastric contents, toxic chemicals and other foreign matter can injure the lung or cause airway obstruction $^{3}$. This was a major problem among the patients admitted after tsunami.

\section{Seawater aspiration}

Seawater is hypertonic; therefore the osmotic gradient draws interstitial and intravascular fluid into the alveoli, causing "secondary drowning", Secondary drowning is a phenomenon in which respiratory deterioration occurs as a result of pulmonary oedema between 1-72 hours of near drowning. Furthermore, seawater inactivates surfactant, resulting in an increase in alveolar surface tension and causing atelectasis of alveoli ${ }^{3}$.

\section{Fluid and electrolyte alterations}

Massive seawater ingestion or aspiration can lead to electrolyte changes and fluid shifts causing hypernatraemia \& haemoconcentration. However, with the exception of pulmonary oedema, clinically significant fluid shifts are uncommon. Therefore substantial changes in serum electrolytes are rarely seen ${ }^{3}$.

\section{Hypothermia}

Near drowned patients are frequently hypothermic. Children are at an increased risk of hypothermia as a result of higher body surface area to weight, decreased subcutaneous fat and limited thermogenic capacity. The body temperature depends on water temperature, insulation provided by clothing, and the volume of aspirated water. Large volumes of water can 
cause rapid central cooling ${ }^{4,5,6}$. The implications and consequences of hypothermia in near drowned victims are the subject of significant controversy and confusion. Although severe hypothermia may rarely confer some degree of neurological protection, its pathological implications are more commonly detrimental, if not rapidly corrected. Moderate to severe hypothermia leads to progressive bradycardia and impairs myocardial contractility leading to inadequate perfusion and shock while the central respiratory centre depression results in hypoventilation and eventual apnoea ${ }^{5,6,7}$. Deep coma with fixed dilated pupils and absent reflexes at very low body temperatures, below $25-29^{\circ} \mathrm{C}$ may be misleading giving the false appearance of death.

\section{Associated injuries}

Falling structures and water full of swirling debris inflict crush injuries, fractures, internal organ injuries and head injuries. In a disaster of this nature, electrocution is also a possibility.

\section{Stage I of the presentation}

Immediately after tsunami, deaths and injured were brought to Teaching Hospital Karapitiya, Galle which is the premier hospital in Southern province. Teaching Hospital, Karapitiya statistics on 26.12.2004 are shown in table 4.

Table 4

\begin{tabular}{|l|l|}
\hline $\begin{array}{l}\text { No. of dead bodies brought } \\
\text { immediately after tsunami }\end{array}$ & 1300 \\
\hline No. of patients treated at ETU & Unknown \\
\hline Total number of admissions & 950 \\
\hline
\end{tabular}

Devastated public and the grieving relatives carrying affected children were directed straight to the paediatric ward, without keeping any records, to relieve the workload at the 3-bed emergency treatment unit. All these patients were seen by me personally and managed under my supervision by a team of dedicated staff members of the ward, well supported by a few other hospital members. A retrospective analysis was carried out to describe the characteristics and the outcome of those drowned and neardrowned victims of Tsunami, brought to the paediatric ward.

\section{Results and comments}

Total number of children brought was 61 . Out of them $45(73.7 \%)$ were managed in the general paediatric ward while the rest, $16(26.3 \%)$, were treated in the NICU. (Table 5)

Table 5

\begin{tabular}{|l|c|}
\hline Ward & Number (\%) \\
\hline Paediatric ward & $45(73.7)$ \\
\hline NICU & $16(26.3)$ \\
\hline Total & $61(100)$ \\
\hline
\end{tabular}

Sex distribution is shown in table 6. The male to female ratio was 1.1: 1.0.

Table 6

\begin{tabular}{|l|c|}
\hline Sex & Number (\%) \\
\hline Female & $29(47.5)$ \\
\hline Male & $32(52.5)$ \\
\hline Total & $61(100)$ \\
\hline
\end{tabular}

Age distribution is shown in table 7. Ages ranged from one day to 12 years, with a mean of 30 months. $70 \%$ were less than 4 years of age. Ages of 2 unidentified deaths were unknown.

Table 7

\begin{tabular}{|l|c|}
\hline Age & Number (\%) \\
\hline Unknown & $02(03.3)$ \\
\hline$<7$ days & $09(14.7)$ \\
\hline $7-30$ days & $02(03.3)$ \\
\hline $1-3$ months & $09(14.7)$ \\
\hline $3-6$ months & $04(06.5)$ \\
\hline $6-12$ months & $06(09.8)$ \\
\hline $1-3$ years & $09(14.7)$ \\
\hline $3-5$ years & $12(19.6)$ \\
\hline $5-10$ years & $07(11.4)$ \\
\hline$>10$ years & $01(01.6)$ \\
\hline Total & $100(100)$ \\
\hline
\end{tabular}

Identification on admission is shown in table 8 .

Table 8

\begin{tabular}{|l|c|}
\hline Identification on admission & Number (\%) \\
\hline Identified & $35(57.4)$ \\
\hline Unidentified & $26(42.6)$ \\
\hline Total & $61(100)$ \\
\hline
\end{tabular}

At the time of admission only 35 (57.4\%) were identified. Apart from 4 children who were identified very late, all others were identified over the next 72 hours. A $2 \frac{1}{2}$ year old little girl who lost her mother and brother was the last to be identified. She became emotionally attached 
and dependent on a medical officer and behaved as if nothing happened. The father who was desperately searching his daughter reunited with her after 3 days. Last to leave the ward was a six year old mentally retarded boy who is an inmate of Sambodi home for children with special needs. This home was badly damaged with heavy loss of life. He is one of the 41 lucky survivors when 42 other residents of the home drifted away to their deaths.

Physical examination findings are shown in table 9.

Table 9

\begin{tabular}{|l|c|}
\hline Examination Findings & Number (\%) \\
\hline Hypothermia only, GCS 15 & $03(04.9)$ \\
\hline $\begin{array}{l}\text { Hypothermia, tachypnoea } \\
\text { without cyanosis, GCS 15 }\end{array}$ & $03(04.9)$ \\
\hline $\begin{array}{l}\text { Good respiratory effort with } \\
\text { tachypnoea, with cyanosis, } \\
\text { GCS 10-12 }\end{array}$ & $25^{*}(40.9)$ \\
\hline $\begin{array}{l}\text { Poor respiratory effort, } \\
\text { cyanosis, GCS 8-10 }\end{array}$ & $25(40.9)$ \\
\hline $\begin{array}{l}\text { No respiratory effort with } \\
\text { cardiac beat and } \\
\text { unresponsive, GCS 3-5 }\end{array}$ & $03(04.9)$ \\
\hline $\begin{array}{l}\text { No respiratory effort } \\
\text { without cardiac beat and } \\
\text { unresponsive, GCS 3 }\end{array}$ & $02(03.3)$ \\
\hline Total & $61(100)$ \\
\hline
\end{tabular}

* Upper airway obstruction giving rise to stridor was seen in 3 patients.

Although the exact temperature reading was not recorded under the prevailing circumstances, all our patients were cold and hypothermic on admission. Immediately after the resuscitation, re-warming measures were initiated and their body temperature was monitored closely.

\section{Method of resuscitation}

Fifty five $(90 \%)$ of them needed resuscitation to restore oxygenation, ventilation and circulation with clearance of airway of vomitus and foreign material such as sand, mud and other debris. Out of the $6(10 \%)$ patients who did not need resuscitation 3 were only hypothermic while the other 3 were hypothermic and tachypnoeic with bilateral crepitations and rhonchi. The method of resuscitation is shown in table 10 .
Table 10

\begin{tabular}{|l|l|l|}
\hline Method used & \multicolumn{2}{|c|}{ Number (\%) } \\
\hline $\begin{array}{l}\text { Supply of } \\
\text { Oxygen \& } \\
\text { airway } \\
\text { clearance }\end{array}$ & $25(40.9)$ \\
\hline $\begin{array}{l}\text { Respiratory } \\
\text { support with } \\
\text { IPPV }\end{array}$ & $30(49.1)$ & $\begin{array}{l}20(32.7) \\
\text { mask } \\
\text { ventilation. }\end{array}$ \\
& & $\begin{array}{l}\text { 10 (16.3) } \\
\text { intubation }\end{array}$ \\
\hline
\end{tabular}

Out of the 30 who needed respiratory support, 5 $(8.1 \%)$ patients had no spontaneous breathing on admission while $25(40.9 \%)$ had ineffective respiration. Ten $(16.4 \%)$ of them needed intubation while others were resuscitated using bag and mask ventilation. Only $2(3.2 \%)$ patients needed long-term intermittent positive pressure ventilation. There was no effective cardiac rhythm in spite of aggressive cardiopulmonary resuscitation in those 5 patients with apnoea and resuscitative efforts were terminated.

\section{Associated injuries}

Seventeen (27.9\%) had associated injuries (table 11). Major injuries noted were compound fractures, cut injuries and damaged cornea.

Table 11

\begin{tabular}{|l|c|}
\hline Injuries & Number (\%) \\
\hline Compound fractures & $04(06.6)$ \\
\hline Corneal injury & $01(01.6)$ \\
\hline Cuts \& bruises & $12(19.7)$ \\
\hline
\end{tabular}

\section{Respiratory complications}

Twenty one had respiratory complications (Table 12). Chest X-rays were performed only on selected patients on clinical suspicion.

Table 12

\begin{tabular}{|l|c|}
\hline Respiratory complications & Number (\%) \\
\hline Pulmonary oedema & $17(27.9)$ \\
\hline $\begin{array}{l}\text { Radiologically proven } \\
\text { aspiration pneumonia }\end{array}$ & $03(04.9)$ \\
\hline Foreign body lung?? & $01(01.6)$ \\
\hline
\end{tabular}

Eighteen (29.5\%) continued to have respiratory distress during the period of hospitalisation as a result of pulmonary oedema \& pneumonia. Four $(6.5 \%)$ others developed respiratory symptoms during the course of the day. Bronchospasm was a significant clinical manifestation noted in 17 
$(27.9 \%)$ of them. Localized and diffused crepitations as a result of pulmonary oedema and pneumonia were other significant findings. In the child in whom the foreign body of the right lung was suspected bronchoscopy was not performed to confirm the diagnosis as the facility was not available. Age distribution of the respiratory complications is shown in table 13.

Table 13

\begin{tabular}{|l|c|l|}
\hline Age & $\begin{array}{l}\text { Number }(\%) \\
\text { Pulmonary } \\
\text { oedema }\end{array}$ & Pumber (\%) \\
\hline$<6$ months & $11(47.8)$ & \\
\hline $6-12$ months & $03(13.0)$ & \\
\hline $1-3$ years & $02(08.7)$ & \\
\hline 3 - 5 years & $02(08.7)$ & $02(08.7 \%)$ \\
\hline$>$ 5 years & $02(08.7)$ & $01(04.3 \%)$ \\
\hline Total & 20 & 03 \\
\hline
\end{tabular}

The majority $(63.6 \%)$ of those who developed respiratory distress were $<1$ year of age.

\section{Neurological Complications}

Fifty five (90\%) were unconscious on admission, 25 of them had a GCS of 10-12 while 25 others had a score of 8-10. The children who had a score of less than 5 did not survive. Two infants, 4 \& 8 months of age developed generalized convulsions after 24 hours of admission most likely as a result of increased intracranial pressure. Possibility of electrolyte imbalance \& intracranial haemorrhage was excluded.

In review of the subject of drowning and near drowning, virtually all authors recommend that patients with submersion episode, including those with a normal physical examination at the time of initial examination should be hospitalised because they are at a risk of an abrupt clinical deterioration $^{4,8,9,10}$. In my study group, $6(9 \%)$ of the children with near-drowning deteriorated with respiratory and neurological complications after initial recovery from the event.

\section{Short term out come}

It is documented that approximately $80 \%$ of paediatric submersion victims survive and $92 \%$ of survivors make a complete recovery ${ }^{3}$. In those children requiring intensive care, just over half survive neurologically intact, but approximately $13-35 \%$ die and $7-27 \%$ survive with severe brain damage $^{11,12}$. In our group $88.5 \%$ survived with complete functional recovery (Table 14).

Table 14

\begin{tabular}{|l|c|}
\hline Out come & Number (\%) \\
\hline Complete functional recovery & $54(88.5)$ \\
\hline Survived in a vegetative state & 00 \\
\hline No. of deaths & $07(11.5)$ \\
\hline Total & $61(100)$ \\
\hline
\end{tabular}

\section{Cause of Death}

This is shown in table 15 .

Table 15

\begin{tabular}{|l|c|}
\hline Cause of death & Number (\%) \\
\hline $\begin{array}{l}\text { Cardiopulmonary arrest } \\
\text { (drowning) }\end{array}$ & $05(08.1)$ \\
\hline Septicaemia and shock & $01(01.6)$ \\
\hline Pneumonia & $01(01.6)$ \\
\hline
\end{tabular}

\section{Analysis of deaths}

This is shown in table 16 .

Table 16

\begin{tabular}{|l|l|l|l|l|l|l|l|}
\cline { 2 - 8 } \multicolumn{1}{c|}{} & Pt. 1 & Pt. 2 & Pt. 3 & Pt. 4 & Pt. 5 & Pt. 6 & Pt. 7 \\
\hline Age & $?$ & $?$ & 3 mths. & 5.5 mths. & 3 Yrs. & $\begin{array}{l}2.5 \mathrm{mths} \\
.\end{array}$ & 7 Yrs. \\
\hline Sex & F & F & M & M & M & M & F \\
\hline Apnoea & Yes & Yes & Yes & Yes & Yes & No & No \\
\hline Heart beat & No & No & Yes & Yes & Yes & Yes & Yes \\
\hline Time of death & $\begin{array}{l}\text { On } \\
\text { admission }\end{array}$ & $\begin{array}{l}\text { On } \\
\text { admission }\end{array}$ & $\begin{array}{l}\text { On } \\
\text { admission }\end{array}$ & $\begin{array}{l}\text { On } \\
\text { admission }\end{array}$ & $\begin{array}{l}\text { On } \\
\text { admission }\end{array}$ & $\begin{array}{l}\text { 4days } \\
\text { later }\end{array}$ & $\begin{array}{l}16 \text { days } \\
\text { later }\end{array}$ \\
\hline GCS score & 03 & 03 & 04 & 03 & 04 & 08 & 08 \\
\hline CPR min & $>30$ & $>30$ & $>30$ & $>30$ & $>30$ & No & 10 \\
\hline
\end{tabular}


Five $(8.2 \%)$ died of drowning immediately after admission. The 3 month old with multiple congenital abnormalities was transferred from maternity hospital following submersion and died 4 days after admission of aspiration pneumonia. The other child was 12 years of age and died following septicaemic shock after a prolonged stay in the ICU. This 12-year-old girl was cyanosed on admission with a very poor respiratory effort and was in circulatory collapse. After immediate CPR she was ventilated on a table in NICU for 48 hours till such time suitable ICU facility was available. After 72 hours of admission, her condition deteriorated with pulmonary oedema as a result of secondary drowning. On day 4, she developed high spikes of temperature with radiological evidence of aspiration pneumonia. A possibility of foreign body in the right lung was raised but bronchoscopy was not performed, as a paediatric bronchoscope was unavailable. As her clinical condition was unsatisfactory she was not transferred to another unit. She succumbed to septicaemia shock and ARDS followed by multi organ failure, 16 days after admission.

Prediction of outcome in near drowning victims is important to guide triage decisions, counsel families, reduce unnecessary interventions, and guide withdrawal of support ${ }^{13}$. Scoring and classification systems as well as individual prognostic factors have been used to prognosticate victims of submersion accidents. Although many strongly correlate with outcome, none is accurate enough to completely differentiate good outcome from poor outcome $\mathrm{e}^{14,15,16,17}$. Factors shown to correlate with outcome include historic variables such as duration of submersion, water or patient temperature and intervention at the scene, treatment variables such as need for CPR in the emergency department, apnoea and pulselessness, depth of coma and neurological response to therapy, and laboratory variables such as $\mathrm{pH}$ and serum glucose $\mathrm{e}^{18,19,20,21}$.

All 5 victims of our study group who did not respond to CPR were apnoeic with a low GCS score. Two of them did not have cardiac beat. As blood gas and blood sugar were not assayed and the temperature readings on admission was not documented we are unable to correlate the outcome of our patients.

\section{Duration of hospital stay}

This is shown in table 17. Majority (75.4\%) were discharged within 3 days of admissions.

Table 17

\begin{tabular}{|l|c|}
\hline Duration of hospital stay & Number (\%) \\
\hline 1 day & $13(21.3)$ \\
\hline $1-3$ days & $33(54.0)$ \\
\hline $3-7$ days & $13(21.3)$ \\
\hline$>7$ days & $02(03.2)$ \\
\hline Total & $61(100)$ \\
\hline
\end{tabular}

\section{Long-term outcome}

This is shown in table 18 . We were able to trace only 43 (75.4\%) out of the 57 survived victims to determine the long-term complications. Six of them were re-admitted with late complications.

Table 18

\begin{tabular}{|l|l|}
\hline Long term out come & \multicolumn{1}{|c|}{ Number (\%) } \\
\hline Late complications & $\begin{array}{l}\text { Meningitis - 02 (3.5) } \\
\text { Pneumonia - 04 (7.0) }\end{array}$ \\
\hline $\begin{array}{l}\text { Permanent } \\
\text { neurological sequelae }\end{array}$ & ? None \\
\hline $\begin{array}{l}\text { Posttraumatic stress } \\
\text { reactions }\end{array}$ & $18(31.5 \%)$ \\
\hline Uncomplicated & $19(33.3)$ \\
\hline Lost for follow up & $14(24.5)$ \\
\hline Total & $57(100)$ \\
\hline
\end{tabular}

\section{Deaths in the family}

These are shown in table 19.

Table 19

\begin{tabular}{|l|l|}
\hline Deaths among family members & No. (\%) \\
\hline Both parents & $02(03.2)$ \\
\hline Father only & $04(06.4)$ \\
\hline Mother only & $06(09.6)$ \\
\hline Other family members & $09(14.8)$ \\
\hline
\end{tabular}

The 2 children who lost both parents are from the same family and on follow up we found that they have been legally handed over to their elder sister for adoption. Only 4 children showed intense emotional reactions during hospital stay $\&$ needed professional help within first 48 hours. These children were over 5 years of age and all of them have witnessed either the mother or the father being washed away. Eighteen (29.5\%) presented with late post-traumatic stress reactions and 6 of them needed specialized opinion as they showed severe stress reactions. 


\section{Difficulties encountered in patient management}

\section{Limited human resources}

Being early morning, on a full moon Poya day, a Sunday, day after Christmas, as one can imagine the hospital staff was not in full scale. Sudden interruption of all the possible communication facilities further compounded the situation.

\section{Limited material resources}

Interrupted power supply created an enormous difficulty in clearing the airways of vomitus or foreign material, which may result in obstruction or aspiration. Abdominal thrusts and back blows on chest were used along with large syringes to clear the airway and it's with gratitude I mention here that some doctors used the mouth as a suction apparatus. Absence of wall oxygen facility and shortage of oxygen supply was a major difficulty. Unstinting supply of medical personnel, resuscitation equipments and drugs from other wards supported us under very trying circumstances.

\section{Bed space}

Some children were resuscitated on floor, as the number of beds was inadequate to manage this magnitude of casualties admitted. To handle this mass casualty, bed space was created by prematurely discharging in-ward patients. No intensive care beds were available. Neonatal Intensive Care Unit, which cares for 8 babies, supported us by taking care of 16 of them and came to the rescue of a 12-year-old child by ventilating the child on a table. All other complicated and uncomplicated children were managed in the general paediatric ward despite the difficulties encountered.

\section{Management of hypothermia and supply of nutrition}

Fellow citizens contributed clothing and nutrients in the greatest hour of need to overcome hypothermia and starvation.

\section{Consoling}

Consoling and providing comforts to physically and mentally traumatised children; the grieving parents and the relatives were a demanding task at this very difficult time.

\section{Stage 2 of the Presentation}

\section{Problems of immediate post disaster phase}

Following a devastation of this nature, disease and death rates among children under five are generally higher than for any other age group. Maintaining the health status among the displaced children in the community became a priority to prevent outbreaks of epidemics and to prevent complications of existing medical conditions. With that in mind my paediatric team with voluntary workers visited 12 camps for displaced, within the first week of devastation.

\section{Following problems were identified.}

1. Loss of medical and immunization records. This was a major concern as the majority are not well conversant with their underlying medical condition. Unsatisfactory medical record keeping in the health sector compounded this situation.

2. The risk of worsening the existing medical condition with the loss of medical devices, inhalers and long-term medications.

3. At least $75 \%$ of child and adult survivors experienced normal stress reactions such as emotional, cognitive and physical reactions, after having witnessed and suffered this distressing and alarming experience.

4. Commonly recognized medical ailments were exacerbation of asthma, viral febrile illnesses, upper and lower respiratory tract infections, minor trauma and skin sepsis. There were no major outbreaks of diseases such as dysentery.

5. The risk of overdosage and wastage of resources. Children were inundated with unnecessary drugs with frequent visits of qualified and unqualified medical personnel without any coordination.

6. The risk of communicable diseases in overcrowded living conditions.

\section{Mobile clinics}

Mobile paediatric clinics were conducted 3 weeks after the disaster to allow better access for all affected children from areas where the infrastructure and social circumstances did not 
allow mobility. The common diseases identified in mobile clinics are shown in this table 20.

Table 20

\begin{tabular}{|l|}
\hline \multicolumn{1}{|c|}{ Diseases } \\
\hline Diarrhoeal illnesses \\
\hline Upper \& lower respiratory tract infections \\
\hline Acute attacks of asthma \\
\hline Cuts, bruises and skin sepsis \\
\hline Scabies \\
\hline Viral fever \\
\hline Symptoms of stress reactions \\
\hline Fear of illnesses after tsunami exposure \\
\hline Routine follow up for chronic diseases \\
\hline
\end{tabular}

We were much concerned about the widely distributed infant formula, which has been done without proper assessment of needs, not adhering to international guidelines. Parents who attended the clinic were asking for advice on preparation of formulae, documented in foreign languages. This would encourage mothers needlessly giving artificial feeds exposing many infants and young children to the increased risk of diarrhoea when clean water is scarce. In most complex emergencies, communicable diseases alone, or more commonly in combination with malnutrition, are the major cause of ill health and death among children. Though the WHO predicted this possibility, the disease pattern observed in these clinics and in the hospital revealed that there were no major epidemics of communicable diseases ${ }^{23,24}$. Information obtained from the national disaster management centre confirmed our observation.

Cumulative number of communicable diseases in temporary camps in the Galle health administrative division as at 18.03.2005 is shown in table 21 .

Table 21

\begin{tabular}{|c|c|c|c|c|c|c|c|c|c|c|}
\hline 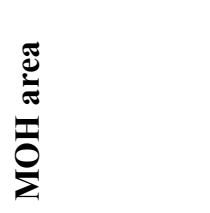 & 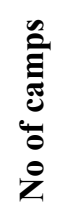 & 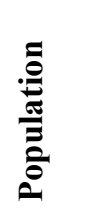 & 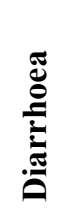 & 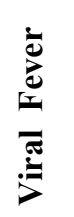 & 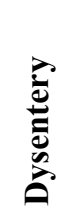 & 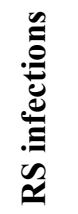 & $\stackrel{\stackrel{0}{E}}{\underline{E}}$ & 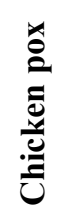 & 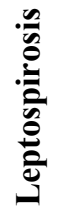 & 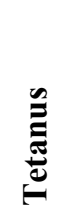 \\
\hline Hikkaduwa & 17 & 1941 & 17 & 1 & - & - & 2 & - & - & - \\
\hline Ambalangoda & 3 & 272 & 19 & 33 & - & 37 & - & 4 & - & - \\
\hline Balapitiya & 6 & 388 & 41 & 72 & - & 91 & - & - & - & - \\
\hline Akmeemana & 1 & 10 & 3 & - & - & 26 & - & - & - & - \\
\hline Karandeniya & - & - & 2 & - & - & - & - & - & - & - \\
\hline MC Galle & 2 & 273 & 6 & - & - & 211 & - & - & - & - \\
\hline Habaraduwa & 1 & 14 & 1 & - & - & 2 & - & - & - & - \\
\hline Total & 30 & 2798 & 89 & 106 & - & 367 & 2 & 4 & - & - \\
\hline
\end{tabular}

Communicable diseases during this complex emergency were largely averted by timely and appropriate interventions of a team of highly motivated medical students from Faculty of Medicine, Ruhuna. Dr. J Weeraman, consultant paediatrician from General Hospital, Matara and other local and foreign paediatricians joined us in performing these clinics. I appreciate with gratitude the overwhelming local and international support offered by supplying drugs and other essentials to make our relief efforts successful.

\section{Stage 3 of the presentation}

\section{Traumatic stress reactions following tsunami}

Many posttraumatic stress symptoms are normal responses to overwhelming stresses. But the intensity of this will subside with time. Amount of time taken to recover depends both on what happened to them and what meaning they give to those events. 
What are normal stress reactions in the wake of a disaster?

1. Emotional reactions - shock, fear, grief, anger, guilt, shame, feeling helpless or hopeless, feeling numb, feeling empty, diminished ability to feel interest, pleasure or love.

2. Cognitive reactions - confusion, disorientation, indecisiveness, worry, shortened attention span, difficulty in concentration, memory loss, unwanted memories, self-blame.

3. Physical reactions - tension, fatigue, edginess, insomnia, bodily aches or pain, nausea.

4. Interpersonal reactions - distrust, conflict, withdrawal, work problems, school problems, irritability, loss of intimacy, feeling rejected or abandoned.

Studies show that as many as one in three disaster survivors have severe stress symptoms that put them at risk for lasting post-traumatic stress disorder (PTSD).

What aspects of disaster are specially traumatising? ${ }^{24,25}$

The following are likely to put survivors at risk of severe stress symptoms and lasting PTSD.

- Life threatening danger or physical harm (especially to children).

- Exposure to gruesome death or human violence or destruction.

- Loss of home, valued possessions, neighbourhood, or community.

- Loss of communication with or support from close relations.

- Intense emotional demands (rescue personnel and care givers searching for possibly dying survival or interacting with bereaved family members.

- Extreme fatigue, hunger and sleep deprivation.
- Extended exposure to danger, loss, emotional and physical stray.

Which individuals are at risk for severe stress responses?

Some individuals have a higher than typical risk for severe stress symptoms and lasting PTSD including those with a history of:

- Exposure to other traumas e.g.: accidents, abuse, assaults and combat.

- Chronic medical illness or psychological disorders.

- Chronic poverty, homelessness, unemployment or discrimination.

- Recent or subsequent major life stressors or emotional strain (single parenting).

Disaster stress may revive memories of prior trauma and may intensify pre-existing social, economic, spiritual, psychological or medical problems.

\section{Case report}

12-year-old Nisansala, a direct victim of this disaster, was brought after near drowning and said that the tsunami swept her whole family (parents, 1 sister and 2 brothers) to their deaths. She was in a state of shock and was withdrawn and mute. She was neglecting herself and had feelings of guilt. On $28^{\text {th }}$ of December, Nisansala was able to smile after a surprised reunion with her 10 year old sister Thilini who was found among adult patients in the same hospital. Unlike Nisansala she did not show any evidence of posttraumatic stress. She was very playful and cheerful. Two days after reunion, the children were identified by their grandparents and handed over after informing the probation and childcare. On further follow up it was confirmed that they have been legally handed over to their aunt and have recovered from post-traumatic stress.

Details of post-traumatic stress reactions among patients seen in Hospital and in Private sector from 15.01.2005-30.04.2005 are shown in table 22. 
Table 22

\begin{tabular}{|l|l|}
\hline $\begin{array}{l}\text { Symptoms of posttraumatic } \\
\text { stress }\end{array}$ & No. (\%) \\
\hline Sleep disturbances & $21(09.9)$ \\
\hline Depressive symptoms -crying & $17(08.0)$ \\
\hline $\begin{array}{l}\text { Somatic complaints-chest } \\
\text { pain, abdominal pain, } \\
\text { headache }\end{array}$ & $68(32.0)$ \\
\hline $\begin{array}{l}\text { Repeated questioning \& } \\
\text { seeking reassurance }\end{array}$ & $13(06.1)$ \\
\hline $\begin{array}{l}\text { Regressive behaviour-thumb } \\
\text { sucking, bed wetting, } \\
\text { stammering }\end{array}$ & $28(13.2)$ \\
\hline Irritability-temper outbursts & $32(15.0)$ \\
\hline Visual hallucinations & $05(02.3)$ \\
\hline $\begin{array}{l}\text { Re-enactment of the event in } \\
\text { play activity }\end{array}$ & $03(01.4)$ \\
\hline $\begin{array}{l}\text { Fearful anticipation of } \\
\text { recurrent of event-school } \\
\text { refusal, refusing to live in the } \\
\text { same house and ground floor }\end{array}$ & $115(54.0)$ \\
\hline $\begin{array}{l}\text { Disturbed attention \& poor } \\
\text { concentration at school }\end{array}$ & - \\
\hline
\end{tabular}

From 15.01.2005 to 30.04 .2005 a total of 212 children with multiple symptoms of posttraumatic stress were seen in the private sector and in hospital. Out of them 9 (4.24\%) needed hospitalisation while $56(26.4 \%)$ needed opinion from the consultant psychiatrist, as the symptoms were severe.

\section{Case report}

Sithara Dilhani, a 14 year old girl from Hikkaduwa, who lost both her grandparents and all her belongings, was admitted to ward with a history of unbearable chest pain. She showed features of severe post-traumatic stress. During the hospital stay, she demonstrated the reenactment of the event by drawing pictures of the disaster.

Described above are normal reactions to extremely dangerous stressful situations where people have felt helpless. The majority of them will experience these reactions only for a short period of time. For people to get through these normal reactions and reduce further distress, basic and other practical needs were provided by local and international donor agencies. The UNICEF backed programme of psychosocial care sessions have enormously helped the children to recover.

\section{Stage 4 of the presentation}

\section{Impact and challenges of camp settings}

A further study was undertaken from 01.03.2005 to 30.04 .2005 to identify health hazards, emotional and psychosocial problems among the displaced children living in temporally shelters. A pre-tested, 10-item, 2-paged, intervieweradministered questionnaire with close-ended and a few open-ended items, was employed as the data collection tool. Chief occupants of 95 tents from 10 randomly selected camping sites in Galle health administrative division were interviewed by trained medical undergraduates. Information was collected on household composition, health hazards, social and psychosocial problems, sanitation, availability of recreational centres and facilities for study and play for children. Conditions of tents and environment are based on the observations made by the interviewer.

\section{Results and comments}

Number of occupants in each tent is shown in table 23 .

Table 23

\begin{tabular}{|l|c|}
\hline No of occupants & Number (\%) \\
\hline$<3$ & $16(16.8)$ \\
\hline $3-5$ & $48(50.5)$ \\
\hline$>5$ & $31(32.6)$ \\
\hline Total & $95(100)$ \\
\hline
\end{tabular}

Adequacy of ventilation is shown in table 24 . $83 \%$ of the tents were overcrowded and $75.7 \%$ of those were poorly ventilated providing favourable conditions for respiratory infections.

Table 24

\begin{tabular}{|l|c|}
\hline Ventilation & Number (\%) \\
\hline Yes & $23(24.3)$ \\
\hline No & $72(75.7)$ \\
\hline Total & $95(100)$ \\
\hline
\end{tabular}

The age distribution of the children is shown in table 25. Out of the total number of occupants (277), 34.6\% were below 16 years of age.16\% pre of them were pre school children. 
Table 25

\begin{tabular}{|l|c|}
\hline Age (Years) & Number (\%)* \\
\hline$<1$ & $09(03.2)$ \\
\hline $1-3$ & $14(05.2)$ \\
\hline $3-5$ & $21(07.6)$ \\
\hline $5-12$ & $44(15.8)$ \\
\hline $12-16$ & $08(02.8)$ \\
\hline$>16$ & $181(65.4)$ \\
\hline Total & $277(100)$ \\
\hline $\begin{array}{l}\text { *Percentages were calculated from } \\
\text { the total number of occupants }\end{array}$
\end{tabular}

$35 \%$ were reported to have lost their medical and immunization records. Though the school attendance was satisfactory, $57.4 \%$ parents felt that the concentration on schoolwork is affected. This was further confirmed in a survey of 12 randomly allocated tsunami affected schools. It revealed, while the overall school attendance has improved anticipating donations; the concentration on schoolwork was markedly affected. Teachers attributed this lack of concentration to the following.

1. Unfavourable conditions prevailing in schools and in the camps.

2. The parents who with the least panic rumour removing their children from schools at all odd times anticipating another tsunami

3. Frequent visits by donor agencies to schools and to camps.

Environmental conditions are shown in table 26.

Table 26

\begin{tabular}{|l|l|l|l|}
\hline $\begin{array}{l}\text { Satisfac } \\
\text { tory }\end{array}$ & $\begin{array}{l}\text { Water } \\
\text { supply } \\
\mathbf{( \% )}\end{array}$ & $\begin{array}{l}\text { Drainage } \\
\text { of water } \\
\mathbf{( \% )}\end{array}$ & $\begin{array}{l}\text { Waste } \\
\text { disposal } \\
\mathbf{( \% )}\end{array}$ \\
\hline Yes & $82(86.3)$ & $24(25.3)$ & $71(74.7)$ \\
\hline No & $13(13.7)$. & $71(74.7)$ & $24(25.3)$ \\
\hline Total & $95(100)$ & $95(100)$ & $95(100)$ \\
\hline
\end{tabular}

Environmental problems were a major concern. Inadequate drainage system was reported in $74.7 \%$ of the tents and water collections in and around campsites were noticed in $36.6 \%$. Supply of water and disposal of waste was satisfactory in $86.3 \%$ and $74.7 \%$ respectively. In $85.3 \%$ of tents meals were prepared in the area at the entrance to the tents and $38.9 \%$ used kerosene oil for cooking.
Health problems following tsunami are shown in Table 27.

Table 27

\begin{tabular}{|l|c|}
\hline Health Problems & No. (\%) \\
\hline Dermatological conditions & $09(03.2)$ \\
\hline $\begin{array}{l}\text { Sleep Disturbances, somatic } \\
\text { complaints and other stress reactions }\end{array}$ & $62(22.3)$ \\
\hline Respiratory infections & $08(02.8)$ \\
\hline Dysentery & $09(03.2)$ \\
\hline Accidental ingestion of kerosene oil & $03(01.0)$ \\
\hline
\end{tabular}

The significant health problems identified were dermatological conditions (3.2\%) such as scabies sweat rash and atopic dermatitis and posttraumatic stress presenting as sleep disturbances, bedwetting and somatic complaints (22.3\%). Other communicable diseases such as acute respiratory tract infections and outbreaks of dysentery were reported only in $2.8 \%$ and $3.2 \%$ respectively. Although there were favourable conditions for acute respiratory illnesses only $13 \%$ of the parents/guardians felt that the frequency of the asthma among their children was increased while residing in the camps. Accidental ingestion of kerosene oil was documented in $1 \%$ of children. Although the risk of accidental injuries to children was anticipated it was not a problem in this study population of children. Intolerable heat and overcrowded living conditions contributed to the skin manifestations noticed in our study group.

The factors promoting communicable disease transmission interact synergistically in complex emergencies. These factors include mass population movement and resettlement in temporary locations, overcrowding, impoverishment, scarcity of safe water, poor sanitation and waste management, poor nutritional status and poor access to health care $^{26,27}$. We can be proud that we have contained the risk of transmission of communicable diseases with appropriate and timely interventions. However it is well shown in our study that overcrowding in poorly ventilated camping sites with poor wastewater management is an important issue, which needs to be addressed to prevent epidemics of dengue and other mosquito transmitted diseases.

Research evidence supports that psychological morbidity in children after natural disasters can be high and widespread. In our study $22.3 \%$ of children suffer from stress reactions such as 
sleep disturbances in the form of nightmares and sleep walking and somatic complaints. These are transient in the majority and will disappear without any intervention. The medium and longterm psychological impact of the tsunami in Sri Lanka is not well understood. It is possible that a high prevalence of long-term post disaster mental health problems would be $\operatorname{seen}^{28}$. Fulfilling the basic health needs is an essential aspect of preventing adverse mental health consequences. The longer-term outlook for the children will depend on the resumption of ordinary life within the family and the community. These children should be adequately supported and involved in routing activities.

Out of the 10 camping sites only 4 had facilities for play and recreation. None of the guardians feared sexual abuse to their children. In contrast $100 \%$ feared a possibility of another tsunami and felt uneasy to spend the night. The majority said that there is no proper disaster plan and a warning system.

\section{Conclusions}

Never has Sri Lanka faced a natural disaster on the scale that we witnessed on the $26^{\text {th }}$ of December 2004. The time has come to face the bitter truth that we are not immune to earthquakes. Now that we know for certain that the entire region is at risk, there should be increased regional and international cooperation on mitigating impact of such disasters. A mass casualty management system should be established to respond to similar disasters with pre-established procedures for resource mobilizations, field management and hospital reception. Despite extensive damage to the country the situation has improved significantly. Sri Lanka is shifting increasingly from an acute emergency phase to one of consolidation and reconstruction. However, the situation remains acute in several areas, particularly sanitation, living conditions with unbearable heat and infrastructure. Construction of shelters with essential facilities as urgently as possible, is recommended. Nature has dealt us a sever blow; we have to come to terms with the enormity of this calamity and collectively do our best to get the country and our children back on track.

\section{References}

1. Tsunami 2004. Available from: http://www.nipissingu.ca/faculty/ingridb/Ge ology/Tsunami\%202004.htm

2. Tsunami Press Room. Available from: http://www.unicef.org/media/media_24628. $\underline{\text { html }}$

3. Shepherd S M, Martin J. Submersion Injury, Near Drowning. Last Updated: July 19, 2005. Available from: http://www.emedicine.com/emerg/topic744. $\underline{\mathrm{htm}}$

4. Quan L, Kinder D. Pediatric submersions: prehospital predictors of outcome. Pediatrics 1992; 90:909-13.

5. Kram J A, Kizer K W. Submersion injury. Emerg Med Clin North Am 1984; 2:545-52.

6. Jacobsen W K, Mason L J, Briggs B A, Schneider S. Thompson J C. Correlation of spontaneous respiration and neurological damage in near drowning. Crit Care Med 1983; 11:487-9.

7. Graf W D, Cummings P, Quan L, Brutocao D. Predicting outcome in pediatric submersion victims. Ann Emerg Med 1995; 26:312-9.

8. Botkin J R Delivery room decisions for tiny infants: An ethical analysis. J Clin Ethics 1990; 1:306-11

9. Fischer A F, Stevenson D $\mathrm{K}$ the consequences of uncertainty. JAMA 1987; 1929-193.

10. Modell J H Drowning: to treat or not to treat-an unanswerable question? Crit Care Med 1993; 21:313-5.

11. Kyriacou D, Arcinue E, Peek C, et al: Effect of immediate resuscitation on children with submersion injury Pediatrics 1994; 94:137.

12. Kemp A M, Sibert J R, Drowning and near drowning in children in the United Kingdom. Lesson for prevention. BMJ 1992; 304:1143-6. 
13. Allman F D, Nelson W B, Pacentine G A, McComb G. Outcome following cardiopulmonary resuscitation in severe pediatric near-drowning. Am J Dis Child 1986; 140:571-5.

14. O'Rourke P P. Outcome children who are apneic and pulseless in the emergency room. Crit Care Med 1986; 14:466-8.

15. Lavelle J M, Shaw K N. Near drowning: is emergency department cardiopulmonary resuscitation or intensive care unit cerebral resuscitation indicated? Crit Care Med 1993; 21:368-73.

16. World Health Organization. Flooding and communicable diseases fact sheet: risk assessment and preventive measures. http:/www.who.int/hac/techguidance/ ems/flood_cds/en/)

17. Connolly M A, Gayer M, Ryan M J, Salama P, Spiegel P, Heymann D L. Communicable diseases in complex emergencies: impact and challenges. Lancet 2004; 364:1974-83.

18. World Health Organization. Mental health assistance to the populations affected by the Tsunami in Asia: introduction and population perspective.

19. Core group for disaster management Faculty of Medicine University of Colombo: Guidelines for disaster management 2005.

20. Humanitarian charter and minimum standards in disaster response. Rev. ed. Geneva: Sphere Project, 2004.
21. Burkholder B T, Toole M J. Evolution of complex disasters. Lancet 1995; 346: 1012 5.

22. World Health Organization. Flooding and communicable diseases fact sheet: risk assessment and preventive measures. http:/www.who.int/hac/techguidance/ ems/flood_cds/en/)

23. Connolly M A, Gayer M, Ryan M J, Salama P, Spiegel P, Heymann D L. Communicable diseases in complex emergencies: impact and challenges. Lancet 2004; 364:1974-83.

24. World Health Organization. Mental health assistance to the populations affected by the Tsunami in Asia: introduction and population perspective.

25. Core group for disaster management Faculty of Medicine University of Colombo: Guidelines for disaster management 2005.

26. Humanitarian charter and minimum standards in disaster response. Rev. ed. Geneva: Sphere Project, 2004.

27. Burkholder B T, Toole M J. Evolution of complex disasters. Lancet 1995; 346: 1012 5.

28. H. Perera, The challenge of providing mental health care for children after the tsunami. Sri Lanka Journal of Child Health, 2005; 34: 3-4. 